\title{
Građevni redovi i regulatorno planiranje Zagreba od 1900. do 1918. godine
}

\author{
ZLATKO JURIĆ \\ Odsjek za povijest umjetnosti, \\ Filozofski fakultet Sveučilišta u Zagrebu \\ Zagreb, Hrvatska \\ zljuric@ffzg.hr
}

Nakon neuspjeloga pokušaja zagrebačkoga gradskog načelnika Adolfa Mošinskog i vijećnika Adolfa Hudovskog da se donese građevni red 1894., godine 1908. i 1909. traje rasprava o tri varijante (smjera) realizacije novoga prijedloga građevnoga reda grada Zagreba, koje su razrađene i analizirane u ovome članku.

Prva je varijanta Vladoja Eisenbarta, koji je nastavio i razradio ideju građevnoga reda kao jednoga od osnovnih instrumenata u reguliranju gradova. Eisenbartov tekst iz 1908. preradio je kolektiv autora brojnim primjedbama nakon dugotrajne rasprave u konačni prijedlog iz 1909. godine. Drugu varijantu zagovarali su inženjeri Antun Kostial st., Mirko pl. Ferrich, Kamilo Bedeković i odbor Hrvatskoga društva inžinira i arhitekta, koji su Eisenbartov prijedlog iz 1908. promatrali na dvije razine. Oni su odbacili ideju i svrhu građevnoga reda kao isključivo regulatornoga dokumenta i pretvorili ga u razvojni gospodarski dokument. Odbor se neočekivano preobrazio u žestokoga zagovornika privatnoga vlasništva i poduzetništva. Treću varijantu zastupao je gradski načelnik dr. Milan Amruš, koji je forsirao osnivanje građevnoga odbora i bitno smanjivanje ovlasti i važnosti Gradskoga poglavarstva i zastupstva. Glavni problem u prijedlogu bilo je uvođenje građevnoga odbora kao posebne građevne oblasti koja bi s predloženim ovlastima suspendirala građevnu oblast prve molbe (Gradsko poglavarstvo) i kontrolno djelovanje Gradskoga zastupstva. Bez obzira na postojeće stranačke podjele i osobne animozitete zastupnika, prijedlog osnove građevnoga reda iz 1909. nije imao nikakve izglede prilikom glasanja u Gradskom zastupstvu. 
Ključne riječi: Zagreb; građevni redovi; regulatorno planiranje; XX. stoljeće; Milan Amruš; Vladoje Eisenbart; odbor Hrvatskoga društva inžinira i arhitekta

\section{Uvod}

Nakon pokušaja gradskoga načelnika Adolfa Mošinskog i vijećnika Adolfa Hudovskog s prijedlogom Osnove gradjevnoga reda za slob. i kr. glavni grad Zagreb i inženjera Kamila Bedekovića, Julija pl. Stanisavljevića i odbora Društva inžinira i arhitekta s protuprijedlogom Prerađene osnove građevnog reda za slob. i kralj. glavni grad Zagreb, koji su neuspješno završili 1894., gradska općina ponovo je 1908. pokrenula izradu novoga prijedloga jer građevni red iz 1857. i brojne dopune nisu više bili prikladni za zbivanja u gradogradnji i arhitekturi. ${ }^{1}$ Drugi pokušaj izrade nove osnove građevnoga reda neobičan je po nekoliko značajki. Gradski načelnik dr. Milan Amruš povjerio je mladom inženjeru Vladoji Eisenbartu, koji je od 1905. bio inžinirski pristav u Gradskom građevnom uredu, posao koji je u prethodnom pokušaju 1894. radio najiskusniji i najcjenjeniji gradski stručnjak.

Dopune građevnoga reda od 1900. do 1918. godine

Administrativnom odlukom Zagrebu su 1899. pridružene nove porezne općine: Lašćina, Žitnjak, Jurjevec (donji Maksimir), Petruševac, Borongaj i Vukomerec. Ukupna gradska površina je udvostručena i iznosi $64375 \mathrm{~m}^{2}$ s ukupnim brojem od 57690 stanovnika prema popisu iz 1900. i ostala je nepromijenjena sve do 1945 . godine. ${ }^{2}$ Za razliku od prethodnoga razdoblja, Gradsko zastupstvo (dalje: Zastupstvo) preuzelo je od Odjela za unutarnje poslove Kraljevske zemaljske vlade inicijativu u dopunjavanju građevnoga reda u regulatornom planiranju. Zastupstvo je 1904. donijelo „pravila [...] za gradnju [...] po tz. otvorenom načinu izgrađivanja" u regulatornoj osnovi Ribnjaka. ${ }^{3}$ Gradsko poglavarstvo (dalje: Poglavarstvo) bilo je ovlašteno odrediti otvoreni

1 HUDOVSKI, Osnova gradjevnoga reda za slob. i kr. glavni grad Zagreb, 1-48; HUDOVSKI, Obrazloženje osnove gradjevnoga reda za slob. i kralj. glavni grad Zagreb, 1-25; „Mnienje strukovnoga odbora družtva inžinira i arhitekta u Zagrebu”, 1-36; „Zapisnik plenarne sjednice družtva inžinira i arhitekta u Zagrebu”, 65-66.

2 KLAIĆ, Zagreb 1910-1913. g., 8; FLEISCHMANN, Razvitak Zagreba od najstarijih vremena do danas, 32; TIMET, Stambena izgradnja Zagreba do 1954. godine, 13; KAHLE, „Građevinski propisi Zagreba", 203-215.

3 Zaključak Gr. zastupstva od 6. lipnja 1904., § 112 o regulacijskom planu Ribnjaka; Otpis (potvrda) Kr. zem. vlade, Odjel za unutarnje poslove, od 23. lipnja 1904., br. 48568, u: KAHLE, „Građevinski propisi Zagreba”, 210-211. 
ili poluotvoreni način izgradnje u pojedinim ulicama. ${ }^{4}$ Za slobodno stojeće zgrade širina predvrta između uličnoga i regulatornoga pravca zgrade bila je 3 $\mathrm{m} .{ }^{5}$ Udaljenost zgrade od susjedne međe određena je na $5 \mathrm{~m}$, pa je neizgrađeni prostor između dvije zgrade iznosio $10 \mathrm{~m}$.

Tijekom 1911. potvrđen je Propisnik za izgradnju ljetnikovačkih predjela grada Zagreba, za koje je ustanovljen posve otvoreni ili poluotvoreni način izgradnje. ${ }^{6}$ Pravila postavljena u regulatornoj osnovi Ribnjaka Zastupstvo je razradilo, dopunilo i pretvorilo u Pravilnik (Propisnik) koji je vrijedio na cjelokupnom gradskom području. U otvorenom načinu izgradnje, u masivnoj i laganoj izvedbi, zgrade su slobodno stajale na parceli. Kod poluotvorenoga načina izgradnje mogle su se povezivati dvije do tri zgrade. Pod masivnom izvedbom podrazumijevala se izvedba fasadnih, nosivih i pregradnih zidova od opeke. Pod laganom izvedbom mislilo se na drvenu nosivu konstrukciju s ispunom od opeke. ${ }^{7}$ Zajedničke odrednice bavile su se visinom zgrade i prednjim vrtovima. ${ }^{8}$ Maksimalna visina zgrade bila je dvije etaže (prizemlje + jedan kat). Prednji vrtovi morali su imati minimalnu širinu od $4 \mathrm{~m}$.

Regulatorni pravac zgrade morao je biti paralelan s uličnim pravcem. Ulična ograda imala je maksimalnu visinu zidanoga podnožja od $1 \mathrm{~m}$ i drvenih ili metalnih elemenata visokih $40 \mathrm{~cm}$. Sljedeća mogućnost bila je uređena živica visoka 1,4 m. Ograde prema obje susjedne i dvorišne međe mogle su biti daščane ili zidane i visoke $2 \mathrm{~m} .{ }^{9}$

Ovisno o masivnoj ili laganoj izvedbi zgrada, razlikovale su se minimalna dubina parcele, udaljenost od susjednih međa i duljina ulične fronte. Kod masivne izvedbe bila je propisana minimalna dubina parcele od $26 \mathrm{~m}$, udaljenost od susjedne međe od $5 \mathrm{~m}$ (u iznimnim slučajevima $4 \mathrm{~m}$ ) i minimalna duljina ulične fronte od $18 \mathrm{~m}$. Kod lagane izvedbe bila je propisana dubina parcele od $30 \mathrm{~m}, 10 \mathrm{~m}$ udaljenosti od susjedne međe (u iznimnim slučajevima $8 \mathrm{~m}$ ) i duljina ulične fronte od $28 \mathrm{~m} .{ }^{10}$

\footnotetext{
4 KAHLE, „Građevinski propisi Zagreba”, 211.

Isto.

Zaključak Gr. zastupstva od 6. veljače 1911., \$ 46; Otpis (potvrda) Kr. zem. vlade, Odjel za unutarnje poslove, od 12. travnja 1911., br. 14823, u: Isto; MEŠTROVIĆ, OBAD ŠĆITAROCI, „Propisi i planiranje ljetnikovačkog područja Zagreba”, 114-125; KRTALIĆ, Sustavi planiranja korištenja zemljišta, 31-39; MARINOVIĆ-UZELAC, Teorija namjene površina u urbanizmu, 6266.

KAHLE, „Građevinski propisi Zagreba”, 211-212.

Isto, 211.

Isto.

Isto, 211-212.
} 
Vladoje Eisenbart - prijedlog osnove građevnoga reda za slobodni i kraljevski glavni grad Zagreb, 1908. - 1909.

Tijekom izrade novoga prijedloga građevnoga reda inženjer Vladoje Eisenbart kao podlogu je koristio Osnovu vijećnika Hudovskog iz 1894. i primjedbe odbora Društva inžinira i arhitekta iz iste godine. ${ }^{11}$ Proučio je građevne redove Dresdena (1906.), Düsseldorfa (1907.), Ljubljane (1896.) i Beča (1893.). ${ }^{12} \mathrm{Na}$ sastancima u Poglavarstvu o njegovu prijedlogu detaljno se raspravljalo u travnju 1908. godine. Na skupštini Zastupstva održanoj 4. svibnja 1908. izabran je posebni pododbor koji je o osnovi građevnoga reda raspravljao na sjednicama održanim u lipnju i srpnju te godine. ${ }^{13}$ Poglavarstvo je u srpnju 1908. zatražilo stručno mišljenje Hrvatskoga društva inžinira i arhitekta o osnovi građevnoga reda. Poseban odbor Društva završio je rad na stručnom mišljenju u prosincu 1908., a Poglavarstvo ga je proslijedilo na analizu inženjeru Eisenbartu i pododboru Zastupstva u siječnju 1909. godine. Eisenbart je imao određene primjedbe, koje je protumačio Poglavarstvu. Pododbor je nakon rasprave prihvatio cjelokupno mišljenje odbora Hrvatskoga društva inžinira i arhitekta. Eisenbart je ugradio sve primjedbe pododbora Zastupstva i odbora Hrvatskoga društva inžinira i arhitekta u konačni prijedlog osnove građevnoga reda, koja je bila završena do 17. srpnja 1909. godine. ${ }^{14}$

Tijekom rasprava vođenih 1894. vijećnik Hudovski i inženjeri Bedeković i Stanisavljević jasno su unutar postojećega upravnog postupka definirali nadležnost sudionika u procesu regulatornoga planiranja. Zastupstvo je bilo građevna oblast prve molbe, koja je na prijedlog Poglavarstva odlučivala o promjenama regulatorne osnove, otvaranju novih ulica, mjestima za izgradnju tvornica i ciglana, izgradnji na zemljištima predviđenim za javnu namjenu, gradilištima, izgradnji općinskih zgrada i olakšicama za izgradnju pločnika. Odjel za unutarnje poslove Kraljevske zemaljske vlade bio je građevna oblast druge i posljednje molbe, koja je rješavala žalbe ili potvrđivala odluke Zastupstva.

U definiranju nadležnosti Zastupstva Eisenbart i kolektiv autora prihvatili su iz rasprava vođenih 1894. od sedam stavki samo prve tri, koje su bile fokusirane na regulatorno planiranje. Oni su dodali jednu stavku, prema kojoj Zastupstvo može odobriti određene olakšice odnosno odstupanja od odredbi

11 EISENBART, Osnova gradevnoga reda (1908), 1-102. Osnova se sastojala od 126 članaka podijeljenih u 13 poglavlja.

12 Isto.

13 EISENBART, Osnova Gradevnoga reda (1909), 1.

14 Isto, 1-64 i 1-10 (Dodatak). Građevni red iz 1909. imao je 13 poglavlja i 129 članaka te posebni dodatak: Razvrstavanje gradskih ulica, cesta i trgova u gradevne razrede na temelju ustanova Gradevnoga reda za grad Zagreb. 
građevnoga reda povodom izgradnje u pojedinim gradskim predjelima. ${ }^{15}$ Cijelo gradsko područje bilo je podijeljeno na šest građevnih razreda. ${ }^{16}$ Zastupstvo bi imalo pravo razvrstavanja pojedinih gradskih ulica, cesta, trgova i predjela u pojedine razrede. Građevne parcele trebale bi imati pravokutni oblik u odnosu na ustanovljeni građevni pravac. ${ }^{17}$ Duljina ulične fronte ne bi smjela biti manja od $8 \mathrm{~m}$ za zatvoreni način izgradnje, $12 \mathrm{~m}$ za poluotvoreni i $17 \mathrm{~m} \mathrm{za}$ posve otvoren način izgradnje.

Velika je novost detaljno obrađen postupak komasacije građevnoga zemljišta, koji je bio posljedica inzistiranja na pravokutnom obliku građevne parcele u odnosu na ustanovljeni građevni pravac. ${ }^{18}$ Prije provedbe komasacije gradilišta unutar jednoga građevnog bloka bilo je potrebno dogovoriti s vlasnicima ustupanje zemljišta za javne prometne površine. ${ }^{19}$ Komasaciju određene količine građevnih parcela provodilo bi u prvoj molbi Poglavarstvo na zahtjev najmanje trećine vlasnika ako su posjedovali barem polovicu površina. ${ }^{20}$ U izvedbi bi vrijedilo osnovno pravilo „[...] da svaki učesnik dobiva toliko gradilišta - i brojem i veličinom - po mogućnosti jednakoga položaja, površine i vrijednosti, koliko i kakog je bilo njegovo zemljište prije komasacije". ${ }^{21}$ Tročlano povjerenstvo trebalo je posebno odrediti vrijednost svake zemljišne parcele, zgrade, usjeva i nasada. ${ }^{22}$ Predlagatelji komasacije i ostali vlasnici mogli su imenovati po jednoga člana, a zajedno su birali pročelnika povjerenstva. Ako se nisu mogli dogovoriti, tada bi Poglavarstvo imenovalo drugoga člana i pročelnika povjerenstva. Jedan od članova trebao je biti tehnički stručnjak. ${ }^{23}$ Nakon obavljene procjene vrijednosti zainteresirani vlasnici podnosili bi pismenu molbu za provedbu komasacije Poglavarstvu, koje je moralo organizirati javnu usmenu raspravu s vlasnicima. Ako se vlasnik ne bi odazvao, smatralo se da prihvaća prijedlog komasacije. Nakon završene rasprave Poglavarstvo bi donosilo odluku u kojoj su bili obrazloženi razlozi i potreba komasacije. ${ }^{24}$ Poglavarstvo bi trebalo provesti komasaciju unutar tri tjedna od podnošenja molbe. ${ }^{25}$ Vlasnici su se mogli žaliti u roku od 14 dana na građevnu oblast druge i posljednje molbe, odnosno Odjelu za unutarnje poslove Kraljevske

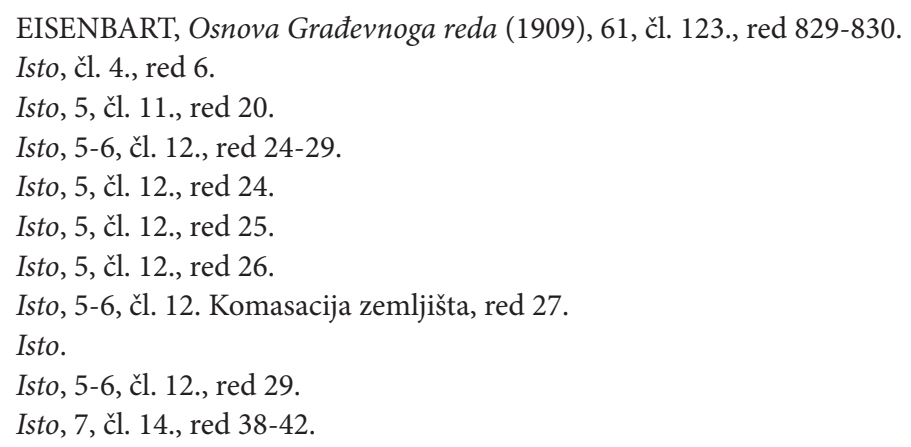


zemaljske vlade. Odobrena parcelacija vrijedila bi tri godine i eventualno bi se mogla produžiti valjanost na sljedeće tri godine.

U raspodjeli troškova pri izgradnji novih ulica postojalo je nekoliko slučajeva. Prvi je slučaj da barem trećina vlasnika koja posjeduje polovicu dužine uličnih pročelja budućih zgrada zatraži otvaranje nove ulice koja je bila predviđena u generalnoj regulatornoj osnovi. ${ }^{26}$ Svi vlasnici zemljišta koja graniče s ulicom morali bi „[...] predati besteretno i besplatno u vlasništvo gr. općine uz čitavu duljinu ceste do polovice njene širine, nu ne preko širine od $10 \mathrm{~m}$. Bude li za cestu više zemljišta trebalo, to ono imade gradska općina odštetiti kao kulturno tlo. U slučaju da jedan međaš dade od svoga zemljišta više nego li je potrebno do širine od $1 \frac{1}{2}$ ceste, tada mu to odštećuje gradska općina kao kulturno tlo. Gradska općina će ovaj višak utjerati od vlasnika suprot ležećih zemljišta, po izmjeri duljine njihova zemljišta". ${ }^{27}$

Ako bi nakon otvaranja regulatornom osnovom predviđene ulice ili ceste jedna od građevnih parcela postala neprikladna za izgradnju, tada je gradska općina bila obvezna čitavo zemljište izvlastiti prema Zakonu o izvlastbi nekretnina. ${ }^{28}$ Osnova za procjenu vrijednosti zemljišta bio bi „[...] prosječni prihod takovog zemljišta u zadnje tri godine, a ima se računati po kamatnjaku od $4 \% ”{ }^{29}$ Troškovi uređenja ulice ili ceste, izvođenja javnoga uličnoga kanala, vodovoda i rasvjete raspodijelili bi se na sve vlasnike građevnih parcela i zgrada prema duljini uličnoga pročelja. Vlasnici bi prije izvedbe radova morali uplatiti procijenjene individualne iznose troškova u gradsku blagajnu.

Drugi je slučaj ako bi vlasnik zemljišta predložio parcelaciju kojom bi se otvorile nove ulice ili ceste i stvorilo više građevnih parcela. Ulice, ceste i putovi nisu bili predviđeni generalnom regulatornom osnovom. Vlasnik bi bio obvezan besplatno ustupiti i prenijeti na gradsku općinu potrebno zemljište, urediti put, ulicu, cestu do propisane visinske razine, izvesti makadam, izgraditi kanalizaciju i vodovod i predati gradskoj općini na uzdržavanje. ${ }^{30}$

Treći je slučaj ako bi gradska općina odlučila otvoriti novu ulicu ili cestu koja je bila predviđena generalnom regulatornom osnovom. Navedeno je prilično maglovito tumačenje specifikacije radova i troškova i načina podjele: „Ako pak gr. općina u sveopćem interesu samo odluči otvoriti i urediti cestu tad će se u smislu gornjega repartirani troškovi, nu bez kamata, ubrati od interesenata u svakom slučaju onom prigodom, kad tko zatraži građevnu dozvolu. Ne može se dati građevna dozvola onomu, koji taj trošak ne podmiri.

Isto, 8, čl. 17., red 44 .

Isto, 8 , čl. 17., red 45 .

Isto, 8 , čl. 17., red 46.

Isto.

Isto, 7, čl. 13., red 37. 
Svi ovakovi troškovi ubiru se političkom ovrhom." ${ }^{31}$ Ostalo je nejasno na koje se troškove mislilo. Odnosi li se to na nabavu zemljišta i uređenje ceste, javnoga uličnoga kanala, vodovoda i rasvjete, ili samo na uređenje ceste, javnoga uličnoga kanala, vodovoda i rasvjete?

U četvrtom slučaju gradska općina uređivala bi u neizgrađenim dijelovima grada trg koji je predviđen generalnom regulatornom osnovom. Vlasnik bi besplatno ustupio zemljište potrebno za ceste, ali bi se morao „[...] ostatak po odbitku površine potrebne za ceste vodeće oko trga, nu ne preko širine od 10 m, platiti posjedniku kao kulturno zemljište". ${ }^{32}$

Na građevnim parcelama bio je predviđen zatvoreni, poluotvoreni i otvoreni način izgradnje. ${ }^{33}$ Odredbe o stvaranju prednjih vrtova u zatvorenom načinu izgradnje istovjetne su prijedlogu Adolfa Hudovskog iz 1894. godine. Jedina je razlika smanjenje minimalne dubine prednjega vrta sa $5 \mathrm{~m}$ na $3 \mathrm{~m} .{ }^{34}$ U poluotvorenom načinu izgradnje mogle bi se dvije ili tri zgrade povezivati $u$ skupinu, a ispred uličnoga pročelja morao se definirati prednji vrt. U otvorenom načinu izgradnje pojedine zgrade gradile bi se odvojeno jedna od druge s ukrasnim vrtom prema uličnom građevnom pravcu..$^{35}$ Dubina prednjega vrta od $5 \mathrm{~m}$ bila je u skladu s prijedlogom Hudovskog. Udaljenost od susjedne međe smanjena je s $10 \mathrm{~m}$ (Hudovski) na $5 \mathrm{~m}^{36}$

U određivanju visine zgrade bila su postavljena dva parametra. Prvi je bio pripadnost ulice ili trga pojedinom razredu. Za svaki razred bio je propisan broj katova u novim zgradama (vidi tablicu 1$).{ }^{37}$

Tablica 1. Visina zgrade prema građevnom razredu

\begin{tabular}{|l|c|c|c|c|}
\hline & Prizemnica & Jednokatnica & Dvokatnica & Trokatnica \\
\hline I. razred & & & $\bullet$ & $\bullet$ \\
\hline II. razred & & $\bullet$ & & $\bullet$ \\
\hline III. razred & & $\bullet$ & $\bullet$ & \\
\hline IV. razred & $\bullet$ & & $\bullet$ & \\
\hline V. i VI. razred & $\bullet$ & $\bullet$ & & \\
\hline
\end{tabular}

Drugi parametar povezivao je visinu zgrade s predviđenom širinom ulice. Visina zgrade trebala je biti usklađena sa širinom ulice ili ceste jer „[...] ne

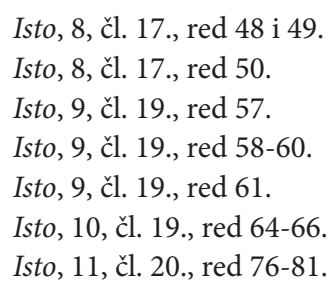


smije da mjeri više od $1 \frac{1}{2}$ cestovne ili ulične širine, a od pločnika pa do gornjeg brida glavnoga vijenca ne smije da prekoračuje maksimum od 25 m". ${ }^{38}$ Posebna je novost da su Eisenbart i kolektiv autora odustali od klasificiranja ulica i cesta po širini.

Osobito osjetljiv problem izgradnje u dvorištima pokušao se riješiti uvođenjem dvaju kriterija. ${ }^{39}$ Prvi je bilo povezivanje minimalne dubine dvorišta u odnosu na visinu dvorišnoga pročelja, koja se mjerila od parapeta najnižega prozora do krovnoga vijenca zgrade. ${ }^{40}$ Prva je varijanta kada su se na dvorišnom pročelju nalazili prozori stambenih prostorija (vidi tablicu 2).

Tablica 2. Visina zgrade prema dubini dvorišta (prva varijanta)

\begin{tabular}{|l|c|c|c|c|}
\hline \multirow{2}{*}{} & \multicolumn{4}{|c|}{ Minimalna dubina dvorišta } \\
\cline { 2 - 5 } & $\begin{array}{c}2 / 3 \text { visine } \\
\text { dvorišne } \\
\text { zgrade }\end{array}$ & $\begin{array}{c}1 / 2 \text { visine } \\
\text { dvorišne } \\
\text { zgrade }\end{array}$ & $\begin{array}{c}\text { 1 visina } \\
\text { dvorišne } \\
\text { zgrade }\end{array}$ & $\begin{array}{c}1,5 \text { visina } \\
\text { dvorišne } \\
\text { zgrade }\end{array}$ \\
\hline I. razred & $\bullet$ & & & \\
\hline II. razred & & $\bullet$ & $\bullet$ & \\
\hline III. razred & & $\bullet$ & & $\bullet$ \\
\hline IV., V. i VI. razred & & & & \\
\hline
\end{tabular}

Druga je varijanta kada na dvorišnom pročelju nije bilo prozora ili su ondje bili prozori nenastanjenih prostorija (služavkina soba, poslovnice) (vidi tablicu 3).

Tablica 3. Visina zgrade prema dubini dvorišta (druga varijanta)

\begin{tabular}{|l|c|c|c|c|}
\hline \multirow{2}{*}{} & \multicolumn{4}{|c|}{ Minimalna dubina dvorišta } \\
\cline { 2 - 5 } & $\begin{array}{c}1 / 3 \text { visine } \\
\text { dvorišne } \\
\text { zgrade }\end{array}$ & $\begin{array}{c}1 / 2 \text { visine } \\
\text { dvorišne zgrade }\end{array}$ & $\begin{array}{c}2 / 3 \text { visine } \\
\text { dvorišne } \\
\text { zgrade }\end{array}$ & $\begin{array}{c}1 \text { visina } \\
\text { dvorišne } \\
\text { zgrade }\end{array}$ \\
\hline I. razred & & $\bullet$ & & \\
\hline II. razred & $\bullet$ & & $\bullet$ & \\
\hline III. razred & & & & $\bullet$ \\
\hline IV., V. i VI. razred & & & & \\
\hline
\end{tabular}


Osim zadovoljenja kriterija u navedenim varijantama, nijedna stranica dvorišta nije smjela biti manja od 6 m (I., II., IV., V. i VI. razred) odnosno $5 \mathrm{~m}$ (III. razred).

Drugi kriterij bavio se minimalnom neizgrađenom površinom dvorišta u zatvorenom načinu izgradnje na građevnoj parceli (vidi tablicu 4). ${ }^{41}$ Eisenbart je detaljnije razradio prijedlog odbora Društva inžinira i arhitekta iz 1894. godine.

Tablica 4. Minimalna neizgrađena površina dvorišta u zatvorenom načinu izgradnje na građevnoj parceli

\begin{tabular}{|l|c|c|}
\hline & U nizu & Uglovnice \\
\hline I. razred & $20 \%$ & $15 \%$ \\
\hline II. razred & $25 \%$ & $15 \%$ \\
\hline III. razred & $20 \%$ & $15 \%$ \\
\hline IV. razred & $30 \%$ & $20 \%$ \\
\hline V. i VI. razred & $35 \%$ & $20 \%$ \\
\hline
\end{tabular}

Iznimke od navedenih kriterija bile bi moguće samo u prvom i trećem građevnom razredu. Kad je postojeća zgrada zauzimala 5/6 površine parcele, prilikom njezina rušenja i podizanja nove zgrade mogla se dozvoliti ponovna izgradnja $\mathrm{u}$ istom opsegu ako bi se novogradnjom poboljšale zdravstvene okolnosti i zaštita od požara. ${ }^{42}$ Ako je dubina parcele omogućavala, mogle bi se izgraditi dvorišne zgrade prema sljedećem principu: „Na građevni pravac dotičnog gradilišta ima se u sredini ulične fronte postaviti okomica i produljiti dok ne prosiječe građevni pravac suprotne prometne površine istoga građevnoga sklopa. Kao pravilo imade tada vrijediti, da otražnji zid dvorišne zgrade ne smije pasti izvan prve trećine duljine okomice računajuć od građevnog pravca gradilišta, na koji se spomenuta okomica postavila." ${ }^{33}$ Udaljenost između prednjega pročelja ulične zgrade i stražnjega pročelja dvorišne zgrade mogla bi biti $1 / 3$ dužine okomice na građevni pravac ulične zgrade do građevnoga pravca susjedne ulice. Od stražnjega pročelja dvorišne zgrade do međe gradilišta moralo bi biti najviše $6 \mathrm{~m}$. U prvom i trećem razredu ne bi se dozvolila izgradnja dvorišne zgrade dok ne bi bila izgrađena ulična zgrada.

U drugom prijedlogu osnove građevnoga reda, iz 1909., Eisenbart i kolektiv autora izradili su posebni dodatak kojega nije bilo u prvom prijedlogu iz

$41 \quad$ Isto, 13, čl. 22., red 102.

42 Isto, 14, čl. 22., red 105-109.

43 Isto, 14-15, čl. 23., red 110-111, 113. 
1908. godine. U dodatku su ulice, ceste i trgovi bili raspoređeni u građevne razrede u kojima su bili definirani maksimalno dozvoljen broj katova, način izgradnje (zatvoreni, poluotvoreni, otvoreni), neizgrađena površina dvorišta (zgrade u nizu, uglovnica), bez olakšica ili s njima. ${ }^{44}$ Prilaz, Frankopanska ulica, Kukovićeva (Andrije Hebranga) ulica i Boškovićeva ulica bili su planirani i izgrađeni prema generalnoj regulatornoj osnovi i svrstani su u prvi razred. U zoniranju volumena postoje očite nelogičnosti. Prilaz je šira ulica od Frankopanske. Na Prilazu je bila predviđena trokatna, a u Frankopanskoj četverokatna izgradnja. Prema pravilu, kad je širina ulice jednaka visini zgrade (1:1), trebalo bi biti obratno. Kukovićeva i Boškovićeva ulica iste su širine i smjera prometa. U Kukovićevoj je dozvoljena trokatna, a u Boškovićevoj četverokatna izgradnja. Zbog iste širine trebala bi biti trokatna izgradnja u obje ulice.

$\mathrm{U}$ industrijske građevine spadale su sve tvorničke zgrade, radionice, skladišta, prostorije uprave i nadzora, obrtničke radionice i prostorije za vođenje trgovine na veliko. ${ }^{45} \mathrm{Na}$ osnovi podjele na čiste i nečiste industrije određen je smještaj u određenim dijelovima grada. Eisenbart je preuzeo prijedlog Hudovskoga gdje bi se mogle smjestiti čiste i nečiste industrije. Čiste tvornice mogle bi se graditi a) južno od pruge državne i južne željeznice, ali ne na zaštitnom pojasu gradskoga vodovoda, b) na području „[... što leži između Srednje ceste, pruge južne željeznice, potoka Černomerca i Ilice, c) zatim izmedju Klaoničke ulice i istočne gradske medje ograničenom na sjeveru Vlaškom ulicom i Maksimirskom cestom a na jugu prugom državne željeznice”. ${ }^{46}$ Poglavarstvo bi odlučivalo od slučaja do slučaja o smještaju čistih tvornica i ciglana u gorskom gradskom predjelu. Nečiste industrije gradile bi se što dalje od gradskoga područja. ${ }^{47}$ Izgradnja tvornica ne bi bila dopuštena na „[... ] Tuškancu, na Josipovcu, Zelengaju, Cmroku, Prekrižju do Šestinske medje, na Pantovčaku i vanjskoj Jurjevskoj ulici". ${ }^{48}$

Prema položaju na parceli, predložena je osnovna podjela na:

a) osamljene zgrade međusobno udaljene barem $20 \mathrm{~m}$, a $10 \mathrm{~m}$ od susjedne međe

b) manje osamljene zgrade međusobno udaljene barem $10 \mathrm{~m}$, a $5 \mathrm{~m}$ od susjedne međe

c) neosamljene zgrade međusobno udaljene od 5 do $10 \mathrm{~m}^{49}$

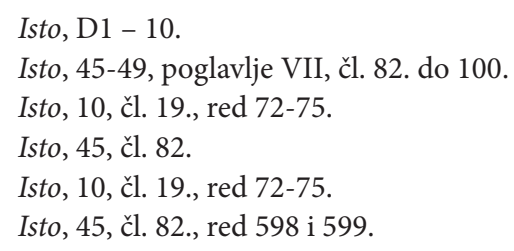


Razmještaj tvorničkih zgrada trebao bi omogućiti upotrebu vatrogasnih sprava pri gašenju eventualnih požara. ${ }^{50}$ Ako se u tvorničkim zgradama proizvode eksplozivne tvari ili uzrokuju jaki smrad, tada bi se zgrade trebale graditi na $50 \mathrm{~m}$ međusobne udaljenosti. ${ }^{51}$

Vladoje Eisenbart i Milan Amruš: Gradsko poglavarstvo ili građevni odbor

Prvi prijedlog Eisenbartove osnove građevnoga reda iz 1908. i konačni prijedlog s kolektivom autora iz 1909. temeljito su se razlikovali u tri slučaja. U prvom slučaju, u Eisenbartovu prijedlogu iz 1908. bilo je predviđeno osnivanje specijalnoga građevnog odbora koji bi mogao odlučivati o odstupanjima od odredbi građevnoga reda u hitnim i izvanrednim slučajevima. ${ }^{52}$ Zastupstvo bi izabralo i potvrdilo deset članova odbora na mandat od dvije godine: četiri člana iz Zastupstva, četiri člana iz Hrvatskoga društva inžinira i arhitekta i po jednoga iz liječničkoga i pravničkoga društva. ${ }^{53}$ Pridruženi članovi bez prava glasa bili bi zapisničar i tehnički činovnik iz Gradskoga građevnog ureda. Poglavarstvo bi pozivalo članove i organiziralo sastanak odbora u svojim prostorima. Na svakoj sjednici članovi odbora birali bi predsjednika, koji bi glasao samo kad bi rezultat bio izjednačen. Odbor bi donosio zaključke apsolutnom većinom glasova. Na sjednici bi moralo biti pet članova da bi zaključci bili pravovaljani. Odluke građevnoga odbora postale bi pravomoćne tek nakon odobrenja Zastupstva. Protiv odluke odbora moglo bi se žaliti Odjelu za unutarnje poslove Kraljevske zemaljske vlade u roku od 14 dana.

Drugi se slučaj odnosio na to da je Zastupstvo moglo odobriti određene olakšice za gradnju radničkih stanova u precizno određenim gradskim predjelima „[... [ ili u drugim važnim slučajevima” ${ }^{54}$ Ostalo je nedefinirano što se podrazumijevalo pod „važnim slučajevima”. Treći slučaj vezan je uz to da je Zastupstvo moglo odobriti odstupanje od arhitektonskih odredbi u građevnom redu prilikom izgradnje radničkih stanova. ${ }^{55}$

Radnički stanovi spadali su u kategoriju stanovanja siromašnijega sloja pučanstva, pa su arhitektonske odredbe bile oskudnije nego u građanskom stanovanju. ${ }^{56}$ Posebno je bizarna odredba da „[...] u svakom katu jedne te iste

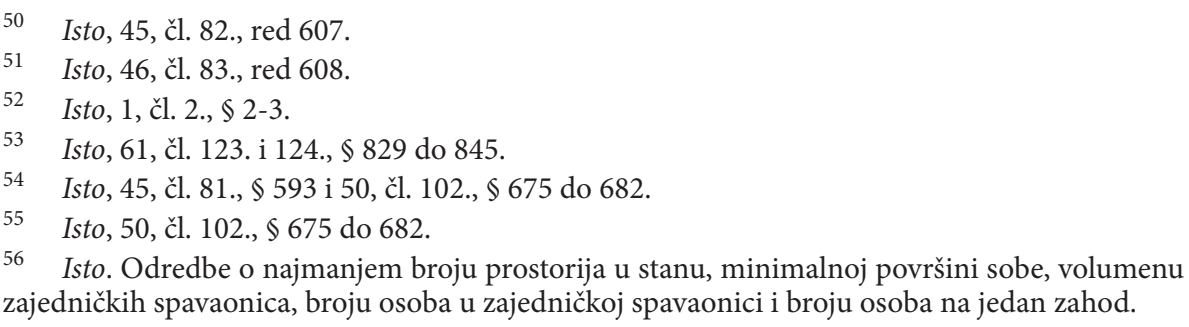


kuće mogu se na zajedničkom hodniku sagraditi najviše četiri po mogućnosti odijeljena stana, tako da stanovnici jednoga stana što manje, najbolje nikako ne dolaze međusobno u dodir" ${ }^{57}$ Zastupstvo je moglo odobriti još oskudnije arhitektonske norme u gradnji radničkih stanova.

Eisenbart i kolektiv autora morali su u konačni prijedlog iz 1909. ugraditi prijedlog gradonačelnika dr. Milana Amruša koji je svojeručno upisao na stranicama prijedloga iz 1908. godine. On je inzistirao da građevni odbor može u sva tri navedena slučaja samostalno donositi odluke, koje bi bile pravomoćne bez konzultacija s Poglavarstvom i potvrde u Zastupstvu.

Amruš je predlagao i drugačiji sastav odbora: smanjenje članova Hrvatskoga društva inžinira i arhitekta na tri i povećanje članova liječničkoga društva na dva. Eisenbart i kolektiv autora nisu prihvatili promjenu broja članova.

Antun Kostial st., Mirko pl. Ferrich, Kamilo Bedeković i odbor Hrvatskoga društva inžinira i arhitekta - ocjena osnove građevnog reda, 1908. $-1909$.

Poglavarstvo je zatražilo stručno mišljenje Hrvatskoga društva inžinira i arhitekta o osnovi građevnoga reda. Na odborskoj sjednici Društva održanoj 17. srpnja 1908. o Eisenbartovu prijedlogu građevnoga reda raspravljali su arhitekt Benko Deutsch, kraljevski tehnički savjetnik Antun Kostial st., ovlašteni civilni arhitekt Martin Pilar i kraljevski inžinir Albert Švarc. ${ }^{58}$ Društvo je odlučilo promijeniti koncepciju u izboru članova u odbor za stručno mišljenje o osnovi građevnoga reda. U prvoj recenziji 1894. izabrali su pet članova (tri iz vlade, dva iz privatnoga sektora) protiv Hudovskog.

$\mathrm{Na}$ Eisenbarta su poslali odbor od 15 članova (pet iz vlade, dva iz grada, osam iz privatne prakse), koji su činili: gradski inžinir Vatroslav Batušić; ovlašteni civilni arhitekt Slavko Benedik; Dušan Birač, kraljevski inžinir i kraljevski vladin povjerenik za nadgledanje parnih kotlova; arhitekt Julije Deutsch, ovlašteni cestovni kraljevski dvorski graditelj; civilni inžinir Adolf Ehrlich; kraljevski tehnički savjetnik Mirko pl. Ferrich; civilni arhitekt Janko Josip Grahor; kraljevski profesor Vinko Hlavinka; ovlašteni civilni arhitekt Janko Holjac; arhitekt Leo Hönigsberg, carski i kraljevski građevinski savjetnik; civilni arhitekt Lav Kalda; ovlašteni civilni mjernik Milan Kreković; kraljevski tehnički savjetnik Antun Kostial st. i ovlašteni graditelj Ivan Štefan. Oni su bili izabrani u posebni odbor koji je trebao izraditi tehničko mišljenje do 15. rujna

Isto, 50, čl. 102., $\$ 677$.

„Zapisnik odborske sjednice od 27. srpnja 1908., 95, čl. 4. 
1908. godine. ${ }^{59}$ Predsjednik odbora bio je iskusni Kostial, a svaki član odbora trebao je kritički obraditi po jedno poglavlje. ${ }^{60}$

U rad odbora uključio se veteran regulatornoga planiranja inženjer Kamilo Bedeković, koji je 1894. sudjelovao u izradi mišljenja o prijedlogu građevnoga reda Hudovskog. On je napravio stilske ispravke i uobličio tekst. ${ }^{61}$

Na društvenoj sjednici održanoj 7. prosinca 1908. potpredsjednik odbora Ferrich pročitao je tehničko mišljenje odbora, koje je jednoglasno prihvaćeno. U uvodu su kurtoazno pohvalili Eisenbarta jer je u iznimno kratkom vremenu napravio golem posao. ${ }^{62}$ On je radio „pomno”, „brižljivo” i „opširno”, a sakupljena je velika građa koja se proteže „na najmanje sitnice građevnih poslova” ${ }^{63} \mathrm{U}$ obrazloženju ocjene odbor je kritički prigovorio koncepciji predložene osnove jer je bila isključivo tehnički dokument. Oni su predlagali potpuni zaokret u razmišljanju o osnovnoj namjeni građevnoga reda. Analizirali su postojeće stanje u stambenoj izgradnji i ustanovili nestašicu kvalitetnih stanova. Posljedica maloga opsega izgradnje bilo je neprekidno poskupljenje stanova. Nedovoljna izgradnja i skupoća stanova utjecale su na stagniranje građevne djelatnosti, koja je usporavala gospodarski razvitak grada. Odbor je zastupao mišljenje da bi se odredbama građevnoga reda trebala poticati građevna djelatnost. Smanjenje troškova u stanogradnji dovelo bi do izgradnje većega broja jeftinih stanova, a posljedice bi bile razvoj građevne djelatnosti i pokretanje gospodarskoga razvoja. Prema mišljenju odbora, kada bi se primijenila predložena Eisenbartova osnova građevnoga reda, izazvala bi potpuno suprotni učinak. ${ }^{64}$ Tehnički normativi u poglavljima IV. („Ustanove o namještanju i visini zgrada te o svjetlu i zraku za prostorije”), V. („Propisi za gradnje”) i VI. („Građevne pogodnosti”) primjer su nametanja pretjerane regulacije koja striktnim i krutim zahtjevima ograničava razvoj građevne djelatnosti. ${ }^{65}$ Odbor je predložio potpunu deregulaciju u tim poglavljima. Osnovni cilj bio bi „[...] da se čim više omogući jeftiniji način gradnje i držeć se načela, da se samo ono propiše ili zabrani, što se iz važnih razloga propisati ili zabraniti mora, a inače, da se onomu, koji hoće da gradi, pusti što veća sloboda”. ${ }^{66}$

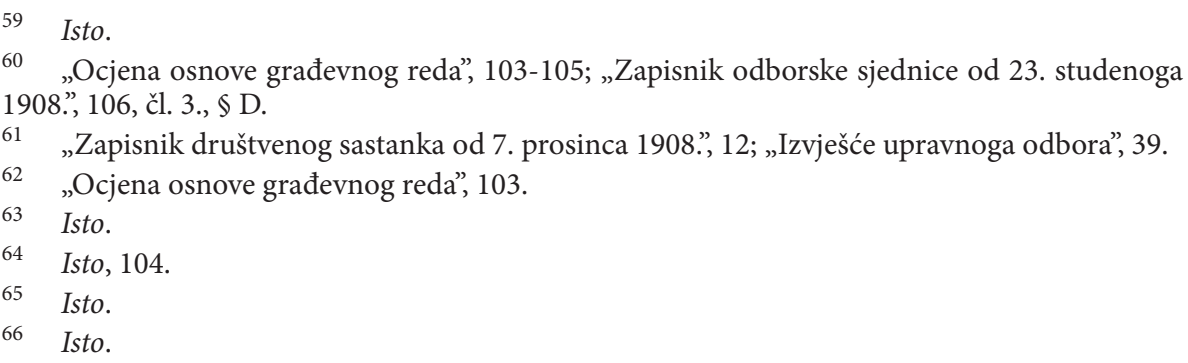


Sljedeći nedostatak bila je pretjerana fiskalna zaštita gradske općine u odnosu na investitora. ${ }^{67}$

Investitor je imao primarne troškove kupnje i parcelacije zemljišta i izgradnje zgrade. Gradska općina nastojala je investitorima nametnuti velike dodatne troškove izgradnje ulice i uvođenja komunalne infrastrukture. Izrazito je negativno ocijenjeno III. poglavlje „O gradilištima” jer „[...] ne pošteđuju niti prava zajamčena u izvlastbenom zakonu, djelomice su iz pravnog gledišta neprovedive, djelomice su nepravedne. Ove ustanove stežu i spriječavaju promet nekretnina i građevnu djelatnost, čine pravni položaj vlasnika zemlje i vrijednost nekretnina nesigurnima" ${ }^{68}$ Odbor je predlagao radikalnu fiskalnu promjenu u ponašanju gradske općine prema investitorima. U prijedlogu građevnoga reda nije postojalo „[...] nastojanja, da se onomu, koji hoće graditi, ide na ruku, da mu se položaj naprama oblasti olakoti, da mu se čim manje troškova nametne". ${ }^{69} \mathrm{U}$ interesu gospodarskoga razvoja odbor je predložio potpuno prerađivanje čitavoga poglavlja „[...] da grad vlasniku gradilišta koji želi graditi ide u susret, kolikogod može a ne sa fiškalnog stanovišta tako, da se iz njega što više izvuče i što više tereta na njega svali” ${ }^{70}$ Oni nisu raspravljali o administrativnim odredbama jer su bile usko povezane s unutrašnjom organizacijom gradske uprave. Kostial, Ferrich i Bedeković predložili su izradu novoga građevnog reda, koji bi bio pregledniji i razumljiviji običnim građanima, a ne samo školovanim inženjerima.

\section{Zaključak}

U raspravi o novom prijedlogu građevnoga reda tijekom 1908. i 1909. postoje tri smjera razmišljanja. U prvome je Vladoje Eisenbart ponudio relativno precizan amalgam prethodnih regulatornih prijedloga Adolfa Hudovskog te Kamila Bedekovića, Julija pl. Stanisavljevića i odbora Društva inžinira i arhitekta iz 1894. godine. On je nastavio i razradio ideju građevnoga reda kao jednoga od osnovnih instrumenata u reguliranju gradova. Kolektiv autora (inženjeri Poglavarstva, članovi pododbora Zastupstva i odbora Hrvatskoga društva inžinira i arhitekta) preradio je osnovni Eisenbartov tekst iz 1908. brojnim primjedbama nakon dugotrajne rasprave u konačni prijedlog iz 1909., koji je još uvijek „tradicionalni” regulatorni instrument. Grad je bio podijeljen na razrede umjesto na okruge. Osnovna jedinica zoniranja postala je ulica, razvrstana u razrede.

\footnotetext{
Isto.

Isto; EISENBART, Osnova Građevnoga reda (1909), 5-9, čl. 11.-18., § 20 do 56.

„Ocjena osnove građevnog reda”, 103.

Isto, 104 .
} 
Zoniranje volumena u ulicama napravljeno je primjenom dvaju modela. Prvi je povezivao širinu ulice i visinu zgrade, propisivao broj katova u zgradama i određivao dubinu dvorišta u odnosu na visinu dvorišne zgrade. Drugi je model određivao postotak neizgrađenosti površine dvorišta. Eisenbart i kolektiv preuzeli su od odbora Društva inžinira i arhitekta iz 1894. preveliku visinu zgrade (1,5 širina ulice) i mali postotak neizgrađenosti površine dvorišta (15\%). U financiranju izgradnje cesta, uređenja trgova i uvođenja komunalne infrastrukture predložena je složena ravnoteža između besplatnoga ustupanja privatnoga zemljišta i obeštećenja vlasnika od gradske općine, koja se mogla interpretirati na različite načine. Novost je definirani postupak komasacije, koju su mogli pokrenuti vlasnici zemljišta, a ne gradska općina. Osnovni je problem građevnoga reda preveliko sužavanje regulatornoga fokusa u procesu zoniranja od gradskoga okruga na pojedinu ulicu.

U drugi smjer spadali su inženjeri Kostial, Ferrich, Bedeković i odbor Hrvatskoga društva inžinira i arhitekta, koji su objavili Ocjenu osnove građevnog reda za slobodni i kralj. glavni grad Zagreb. Oni su Eisenbartov prijedlog iz 1908. promatrali na dvije razine. Na prvoj su odustali od izrade nove ili prerađene osnove građevnoga reda i odlučili se za profesorski pristup jer su zelenom bojom brižno označili ili napisali korekcije arhitektonskih i regulatornih detalja u tekstu. Na drugoj razini odbacili su ideju i svrhu građevnoga reda kao isključivo regulatornoga dokumenta i pretvorili ga u razvojni gospodarski dokument. Odbor se neočekivano preobrazio u žestokoga zagovornika privatnoga vlasništva i poduzetništva. Po njihovu mišljenju, Eisenbartov prijedlog osnove građevnoga reda bio je primjer pretjerane zakonodavne intervencije. Oni su energično zastupali deregulaciju u pravnim i tehničkim normama i fiskalno rasterećenje vlasnika zemljišta i zgrada. Osim regulatornoga planiranja Kostial, Ferrich, Bedeković i odbor Hrvatskoga društva inžinira i arhitekta napravili su kratki i neočekivani izlet u ekonomsku teoriju analizirajući vezu između stambene izgradnje i gospodarskoga razvoja grada. $\mathrm{Na}$ osnovi razmišljanja u tekstu stječe se posve pogrešan dojam da su ga pisali nezadovoljni privatni poduzetnici. U odboru je bilo osam članova iz privatnoga poduzetništva, ali je glavni smjer rasprave određivalo sedam članova iz vlade i grada. Svemoćni vladini i gradski činovnici bili su naviknuti na sveprisutnost i da odlučuju o svemu.

Treći smjer zastupao je gradski načelnik dr. Milan Amruš, koji je forsirao osnivanje građevnoga odbora i bitno smanjivanje ovlasti i važnosti Poglavarstva i Zastupstva. Glavni problem u prijedlogu osnove građevnoga reda iz 1909. uvođenje je građevnoga odbora kao posebne građevne oblasti koja je potpuno nezavisna od građevne oblasti prve molbe (Poglavarstva) i Zastupstva. Neobična je predložena procedura prema kojoj su odluke odbora bile 
pravomoćne bez potvrde u Zastupstvu. U odboru bi bilo šest članova dobrovoljnih strukovnih udruga, koji su mogli nadglasati četiri legitimno izabrana gradska zastupnika u donošenju odluka važnih za gradsku općinu. Bizarna je činjenica da u sastav odbora nije bio predložen nijedan stručnjak iz ureda Poglavarstva. Stvaranje i djelovanje građevnoga odbora s predloženim ovlastima suspendiralo bi ovlasti građevne oblasti prve molbe (Poglavarstva) i kontrolno djelovanje Zastupstva. Bez obzira na postojeće stranačke podjele i osobne animozitete zastupnika, prijedlog osnove građevnoga reda iz 1909. nije imao nikakve izglede prilikom glasanja u Zastupstvu.

\section{Objavljeni izvori i literatura}

EISENBART, Vladoje. Osnova građevnoga reda za slobodni i kraljevski glavni grad Zagreb. Zagreb: Tiskara C. Albrechta (Maravić i Dečak), 1908.

EISENBART, Vladoje. Osnova Gradevnoga reda za slobodni i kraljevski glavni grad Zagreb. Zagreb: Dionička tiskara, 1909.

FLEISCHMANN, Aron. Razvitak Zagreba od najstarijih vremena do danas. Zagreb: Jugoslavenska štampa, 1932.

HUDOVSKI, Adolf. Obrazloženje osnove gradjevnoga reda za slob. i kralj. glavni grad Zagreb. Zagreb: Knjigotiskara i litografija Karla Albrechta, 1894.

HUDOVSKI, Adolf. Osnova gradjevnoga reda za slob. i kralj. glavni grad Zagreb. Zagreb: Knjigotiskara i litografija Karla Albrechta, 1894.

„Izvješće upravnoga odbora podnešeno redovitoj glavnoj skupštini hrvatskog društva inžinira i arhitekta dne 8. veljače 1909.” Vijesti Hrvatskoga društva inžinira i arhitekta u Zagrebu 30 (1909): 39.

KAHLE, Darko. „Građevinski propisi Zagreba u razdoblju od 1850. do 1918. godine”. Prostor 12 (2004), br. 2 (28): 203-215.

KLAIĆ, Vjekoslav. Zagreb 1910-1913. g. Zagreb: Nadbiskupska tiskara, 1918.

KRTALIĆ, Vladimir. Sustavi planiranja korištenja zemljišta. Zagreb: Novi informator, 2004.

MARINOVIĆ-UZELAC, Ante. Teorija namjene površina u urbanizmu. Zagreb: Tehnička knjiga, 1989.

MEŠTROVIĆ, Mirna; OBAD ŠĆITAROCI, Mladen. „Propisi i planiranje ljetnikovačkog područja Zagreba, 1857.-1940.” Prostor 19 (2011), br. 1 (41): 114125.

„Mnienje strukovnoga odbora družtva inžinira i arhitekta u Zagrebu ob osnovi gradjevnoga reda za slob. i kralj. glavni grad Zagreb sastavljenoj po 
gradskomu viećniku gosp. Adolfu Hudovskiju - Preradjena osnova gradjevnoga reda”. Viesti Družtva inžinira i arhitekta 15 (1894), br. 5: (Prilog) 1-36.

„Ocjena osnove građevnog reda za slobodni i kralj. glavni grad Zagreb”. Vijesti Hrvatskoga društva inžinira i arhitekta u Zagrebu 29 (1908), br. 6: 103 105.

TIMET, Tomislav. Stambena izgradnja Zagreba do 1954. godine. Zagreb: JAZU, 1961.

„Zapisnik društvenog sastanka od 7. prosinca 1908.” Vijesti Hrvatskoga društva inžinira i arhitekta u Zagrebu 30 (1909): 12.

„Zapisnik odborske sjednice od 23. studenoga 1908.” Vijesti Hrvatskoga društva inžinira i arhitekta u Zagrebu 29 (1908), br. 6: 106.

„Zapisnik odborske sjednice od 27. srpnja 1908.” Vijesti Hrvatskoga društva inžinira i arhitekta u Zagrebu 29 (1908), br. 5: 95.

„Zapisnik plenarne sjednice družtva inžinira i arhitekta u Zagrebu, obdržavane dne 13. lipnja 1894. u družtvenih prostorijah, pod predsjedanjem gosp. Kamila Bedekovića”. Viesti Družtva inžinira i arhitekta 15 (1894), br. 5: 65-66. 


\section{SUMMARY}

\section{Master Plans and the Regulatory Planning of Zagreb in the 1900-1918 Period}

After the unsuccessful attempt of Zagreb mayor Adolf Mošinski and councillor Adolf Hudovski to secure approval for the Master Plan of 1894, a discussion on three variants (directions) of realising a new master plan of Zagreb took place in 1908 and 1909. This paper elaborates and analyses these three proposals of realising the Zagreb master plan.

The first is the variant of Vladoje Eisenbart, who continued and elaborated the idea of the Master Plan as one of the basic instruments in urban regulation. Eisenbart's text from 1908 was revised by a collective of authors and was, following numerous objections and long discussions, formed into a final proposal in 1909. The second variant was advocated by Antun Kostial, Sr, Mirko Ferrich, Kamilo Bedeković, and a committee of the Croatian Society of Engineers and Architects, who viewed Eisenbart's 1908 proposal on two levels. They rejected the idea and purpose of the master plan as an exclusively regulatory document, and transformed it into a development and economic document. The committee unexpectedly changed into a fierce advocate of private ownership and entrepreneurship. The third variant was advocated by the mayor, Dr Milan Amruš, who forced the founding of a construction committee and substantial limitation of the powers and importance of the city government and council. The main problem in this proposal was the introduction of a construction committee as a separate construction authority that would have, using the proposed powers, suspended the construction authority of the first instance (the city government) and the overseeing activities of the city council. Regardless of the existing party divisions and personal animosities of the city government members, the master plan proposal of 1909 stood no chance at the city council vote.

Key words: Zagreb; master plans; regulatory planning; $20^{\text {th }}$ century; Milan Amruš; Vladoje Eisenbart; Croatian Society of Engineers and Architects committee 